Article

\title{
Political Connections, Government Subsidies and Technical Innovation of Wind Energy Companies in China
}

\author{
Jiaan Qu ${ }^{1,2}$, Jie Cao ${ }^{2, *}$, Xinting Wang ${ }^{1}$, Jiexin Tang ${ }^{3}$ and James O. Bukenya ${ }^{4}$ \\ 1 School of Economics and Management, Nanjing University of Information Science \& Technology, \\ Nanjing 210044, China; qujiaan@nuist.edu.cn (J.Q.); 20131363047@nuist.edu.cn (X.W.) \\ 2 China Institute of Manufacturing Development, Nanjing University of Information Science \& Technology, \\ Nanjing 210044, China \\ 3 College of Economics and Management \& Research Centre for Soft Energy Science, \\ Nanjing University of Aeronautics and Astronautics, Nanjing 211106, China; tjx19910922@nuist.edu.cn \\ 4 College of Business and Public Affairs, Alabama A\&M University, Normal, AL 35762, USA; \\ james.bukenya@aamu.edu \\ * Correspondence: kindcj@nuist.edu.cn
}

Received: 2 September 2017; Accepted: 2 October 2017; Published: 9 October 2017

\begin{abstract}
Developing wind energy is one of the win win measures in response to climate changes and energy security. In order to promote technical innovation in the wind-energy industry, the government grants various fiscal subsidies to wind-energy companies every year. To acquire these subsidies, enterprises often employ those with political backgrounds as members of the board of directors and board of supervisors. On the one hand, the acquisition of subsidies may indeed promote the technical innovation capacity of enterprises, but, on the other hand, due to the existence of "the grabbing hand", the technical innovation capacity of enterprises may be weakened. We selected 35 Chinese wind-energy listed companies to analyze the relationship between political connections, subsidies and the technical innovation capacity. Results indicate that, political connections to an enterprise weaken its innovative potential and achievement. Moreover, the higher the strength of political connections is, the stronger the negative impact it will bring to the innovative capacity of the enterprise. Modulation of government subsidies, however, can alleviate the negative effects of political connections.
\end{abstract}

Keywords: political connections; subsidies; research and development input; patent

\section{Introduction}

Energy is an important input related to economic development and national defense security. Along with the shortage of traditional fossil fuels and the exposure of their defects, more and more countries focus on the development of new sources of energy. By relying on the advantages including cleanliness, renewability, and high availability, wind energy has become one of the main choices among the new forms of energy.

To boost the development of wind power, the U.S. government has successively launched a series of preferential measures, including a policy on the tax offset of wind energy production, a plan of fiscal subsidization under the auspices of the U.S. treasury, and a quota system for renewable energy. By the end of 2015, wind power in the U.S. accounted for $4.7 \%$ of its total electric production, exceeding 190 million megawatt hours, enough to provide for about 17.50 million households. In July 2011, Germany adopted a modification to their Law of Renewable Energy, promoting subsidies for various types of renewable energy and encouraging the development of the renewable energy industry. In 2015, German wind energy output reached 88 terawatt-hours, the European country with the highest output 
in that same year. The British government not only continually adjusts its policies related to wind power and other renewable energies, but is also a pioneer in offshore wind power development and utilization. By the end of 2016, there were 7000 wind-driven generators in the UK, with a total installed capacity of 14 gigawatts. Wind power generation continues to prosper in the European market.

China attaches great importance to the development of wind energy, and has set out many preferential policies such as the yearly granting of various fiscal subsidies to wind-energy companies and supporting the innovation of wind-energy enterprises. According to the official data of the Ministry of Finance, nationally, the total value had been collected from renewable power plus amounted to about RMB 70 billion. This sum of money is used as subsidies for the renewable energy industry.

Such clean energy includes biomass power generation, wind power and solar energy. In their actual operations, enterprises often employ those with political backgrounds as members of the board of directors and supervisors, so as to acquire additional government subsidies. On the one hand, the acquisition of subsidies may indeed promote technical innovation in enterprises, but, on the other hand, due to the existence of "the grabbing hand", the technical innovation capacity of enterprises may be weakened. We therefore focus on the question of how the relationship between government and enterprise executives, and how government subsidies, impact the technical innovation of enterprises. A total of 35 leading enterprises in the Chinese wind power industry are selected as the empirical samples. The results provide policy implications for the innovative development of enterprises, on the one hand, and provide a decision-making reference for the subsidy policies on the other.

\section{Literature Review}

Scholars have already conducted research on the relationship between the political connections or the subsidies and technical innovation.

\subsection{The Impacts of Political Relationships on Technical Innovation}

A number of studies has been conducted on how relationships with government impact the technical innovation of enterprises. However, since different methods and samples were applied, differing research conclusions were obtained. The discussion of whether and, in which direction, government relations impact the technical innovation of enterprises can be chiefly classified into the following three types:

(1) The technical innovation capacity of enterprises is unrelated to political connections. Luk [1] investigated cases in mainland China and Hong Kong, conducted logical reasoning, and held the opinion that it was impossible for political connections to impact technical innovation, both with regards to the market economy and the transitional economy. He looked at this from the perspective of three aspects of social capital: the advantage of teamwork, the advantage of obtaining information and the advantage of social influence. Niu [2] found that the government relevancy of senior executives of state-owned enterprises was weak related to subsidies, and had insignificant impact on the innovative capacity of enterprises.

(2) The political connections can bring significant positive effects to technical innovation in enterprises. As indicated by most early studies, political connections play a positive role in innovation performance. For example, aiming at the Chinese transitional economy, Peng and Luo [3] found that political relations were positively correlated with innovation performance. Song [4] maintained that "a visible hand" and "an invisible hand" simultaneously controlled market resources in a market marked by imperfect competition; enterprises with government relations indeed had less financing limitation than other enterprises, which was beneficial for the innovation input of enterprises. Zeng [5] selected 173 enterprises in Guangdong Province as samples, studied the relationship between the technical innovation of enterprises, political connections and government support to innovation, and found that the setting up of government relationships was the most important approach for enterprises to acquire government support 
for innovation. Zhang and $\mathrm{Lu}$ [6] pointed out that desirable government relationships played a positive intermediary role in the innovation performance.

(3) The political connections with enterprises restrain the technical innovation capacity of enterprises. Recently, more and more studies have revealed that political connections result in weakness of technical innovation by enterprises, instead of improving innovation capacity to enterprises, as theory might suggest. Shleifer and Vishny [7] argued that enterprises had supported the rent-seeking behavior of government officials, which would impair the enterprises' own interests. According to Fisman [8] and Bertrand's findings [9], political connections might bring about a series of problems, including impairing enterprise value, reducing the quality of accounting information, increasing political risks for enterprise operations and increasing ineffective employment. Taking Chinese emerging private companies as a case study, Fan [10] revealed that the political connections of the CEO had a negative impact on the innovation performance of a company after initial public offering. With 1500 Chinese manufacturing enterprises as the sample, Zhang et al. [11] found that government connections would divert management's attention to the internal improvement of enterprises and impair future technical innovation. Yuan et al. [12] examined that Chinese enterprises had, in effect, a political resource curse, and political relevancy hindered the innovative activities of enterprises and reduced innovative efficiency. This negative effect would last until approximately the third year after the enterprise acquired the political connection.

\subsection{The Relationship between Subsidies and Technical Innovation}

To promote the development of the renewable energy industry, various countries worldwide have successively espoused subsidy plans. However, a dispute continues in academic circles over whether the research and development subsidies granted by government to these enterprises are reasonable.

Most scholars affirm the positive role of subsidies to enterprise innovation, because subsidies can reduce the research and development cost of enterprises. For example, Leyden [13] and Mamunesa [14] and Holemans's findings [15] showed that subsidies may push enterprises to expand research and development and promote innovative capacity. Matthias and Czarnitzki [16] comparatively analyzed the differences in innovation between companies which had acquired subsidies and those which had not acquired subsidies, and results indicated that innovative capacity of the former ones had obviously been promoted. Clausen [17] maintained that the innovative subsidies could effectively stimulate research and development in enterprises. This viewpoint was also supported by Montmartin [18], Dumont et al. [19] and Louhivuori [20]. Zhu and Xu [21] illustrated that both the scientific and technological appropriation and tax preference could promote the research and development (R\&D) inputs in enterprises. Tong and Gao [22] proposed the existence of a time-lag effect, indicating that the R\&D expenditure of enterprises was not only subject to current subsidies, but also closely related to previous subsidies. Similar conclusions were also drawn by Liu and Zhang [23], Wang [24] and $\mathrm{Gu}$ [25]. Chen et al. [26] examined that subsidies could effectively stimulate technical innovation in enterprises, especially capital and technology-intensive enterprises with a high creative input.

However, some studies have pointed out that $R \& D$ subsidies would discourage companies from innovating and thereby reduce the innovative capacity of enterprises. Lichteber [27] and Busom [28] pointed out the "crowding out effect" of subsidies; namely, an increase in government subsidies to enterprises enables enterprises to reduce their own R\&D input. This conclusion was reinforced by David [29]. Taking U.S. companies as examples, Impullitti [30] illustrated that subsidies restrained the innovation performance of enterprises.

Obviously, a few studies have been conducted on the relationship among the three variables of political connections, subsidies and technical innovation. Moreover, most studies have ignored the difference between the innovative potential and the innovative achievements of enterprises. Finally, manufacturing was emphasized at the neglect of strategic emerging industries. 
Therefore, with a focus on wind-energy companies, we intensively explore the relationship between political connections, subsidies and the innovative capacity of enterprises. We also take the R\&D input and the annual number of patent applications of enterprises to measure innovative potential and innovative achievements, respectively.

\section{Theoretical Analysis and Research Hypotheses}

\subsection{The Theory of Social Capital}

Social capital usually refers to an individual's capacity for acquiring interest by using his/her own special position in the network of interpersonal relations. The higher the interest an individual can acquire from these relations, the higher his/her social capital becomes. The theory of social capital regards interpersonal relations as an important resource, and the amount of resources held by the actor determines the size of the interest he/she can acquire. A person who owns a desirable network of social relationships can obtain information about investments, management in both a more timely and accurate fashion, thereby leading to the reduction in operation risks for enterprises which may then result in higher economic benefits and the deriving of maximum interest.

With regard to enterprises, establishing close relationships with the government is an important capital, because it can not only bring a lot of advantages to enterprises in, for instance, fund acquisition, technical improvement and market share, but also enable enterprises to enjoy policies including tax reduction and exemption, thus reducing their input of production costs. However, government resources are limited. Even the enterprises which have established relationships with government may also face the situation of a "short supply of government resources". It is impossible for enterprises to acquire interest from government free of charge. In order to acquire income by establishing government relationships, enterprises need to transfer part of their control rights, or make more political donations, as compensation. This may then offset some of the advantages acquired by enterprises from their connections with government, and result in the worsening of innovation performance of enterprises. In addition, political connections may also possibly trigger an "innovative sluggishness" in enterprises. Enterprises may rely too much on the funds, preferential tax and other advantages brought by government resources, thus delaying the self-input of enterprise innovation and reducing the innovative efficiency of enterprises.

Therefore, we put forward the following hypotheses:

Hypothesis 1 (H1). The political connections of enterprises impair the innovative potential and achievement of enterprises. Moreover, the higher the strength of political connections, the stronger the negative impact they will have on the innovative capacity of enterprises.

\subsection{The Rent-Seeking Theory}

"Rent-seeking" means enterprises carry out diplomatic activities by establishing various political relations, expecting to acquire more government support. "Rent" includes such government policies as fiscal subsidies and tax reduction and exemption.

Under the conditions of market competition, resources are allocated through market competition, but market operation is not always perfect. Market functions may be hindered by various factors. At this time, government would intervene in the market and allocate resources with its powers, thus resulting in various extra income points, namely the rent caused by authority, and inducing more and more rent-seeking activities. Government approval, consent, quota, permission, privilege, etc. can all impact resource allocation. In fact, they create a shortage market. Whoever has this market share essentially has a privilege. Therefore, enterprises will seek government enterprise connections to acquire more benefits or "special care". 
However, not all the enterprises that have acquired "rent" apply the funds reasonably as desired by the government. The "crowding out effect" enables enterprises to reduce their own research and development input. After acquiring the rent-seeking benefit, enterprises are sluggish in research and development, and government "rent" eventually impairs the ability of enterprises to pursue innovation and promote their competitiveness, although it can increase enterprise income. In addition, while bringing rent-seeking benefits to themselves through political connections, enterprises must bear a heavy political burden, need to assume part of social responsibility shifted from the government, and also incur much of the non-productive expenditure based on the rent-seeking, so that enterprises have a less free cash flow for R\&D projects.

Therefore, the second hypotheses is as following:

Hypothesis 2 (H2). Political connections impair the innovative potential and achievement of enterprises through subsidies.

\section{Empirical Results and Discussion}

\subsection{Data Source}

Selecting the wind-energy industry as our research object is only based on the following two considerations: (1) The number of renewable energy listed companies as biomass energy, hydrogen energy and hydro-energy companies is small; (2) In general, Chinese wind-energy companies are backward in key technology. The R\&D input of enterprises is crucial for promoting the innovative competitiveness. The 35 wind-energy enterprises led by Sinovel and Goldwind have been selected.

In addition, there is no data of "government subsidy" and " $R \& D$ investment" in the corporate annual report. For the completeness and accuracy of data, we postponed the start time of study to 2009. While the time span is slightly short, as there are 35 wind energy companies, it is still possible to use the panel data techniques. The corporate data was quoted from the financial reports disclosed by the Shanghai Stock Exchange and the Shenzhen Stock Exchange from 2009 to 2015 and the China Stock Market \& Accounting Research Database. All the data were processed with the help of STATA software.

The original data was processed in the following ways: (1) Eliminating samples with abnormal data; (2) Eliminating the impact of inflation for the data of previous years.

\subsection{Models and Variables}

This thesis takes research and development input and patent applications as explained variables, and takes the existence/non-existence of political connections, the strength of political connections and the interaction between government relevancy and subsidies as explaining variables. The panel data models were established, respectively:

$$
\begin{gathered}
\mathrm{LN}\left(\operatorname{R\& D} D_{\text {it }}\right)=\beta_{0}+\beta_{1} \operatorname{Rel}_{\text {it }}+\beta_{2} \text { other control var }+\varepsilon \\
\text { Patent }_{\text {it }}=\beta_{0}+\beta_{1} \operatorname{Rel}_{\text {it }}+\beta_{2} \text { other control var }+\varepsilon \\
\mathrm{LN}\left(\mathrm{R} \& D_{\text {it }}\right)=\beta_{0}+\beta_{1} \text { Relation }_{\text {it }}+\beta_{2}(\text { Relation } * \text { Sub })_{\text {it }}+\beta_{3} \text { other control var }+\varepsilon \\
\text { Patent }_{\text {it }}=\beta_{0}+\beta_{1} \text { Relation }_{\text {it }}+\beta_{2}(\text { Relation } * \text { Sub })_{\text {it }}+\beta_{3} \text { other control var }+\varepsilon
\end{gathered}
$$

where "Patent" denotes patent applications, and "Rel" is used to describe whether the enterprises have political connections. "Relation" denotes the strength of political connections, "Sub" denotes government subsidies, "other control var" denotes various other control variables, and $\varepsilon_{i t}$ denotes random error term. Table 1 is the specific definition of variables, as follows. 
Table 1. Variables and Measurement.

\begin{tabular}{|c|c|c|}
\hline Variable Classification & Variable Symbol & Variable Measurement \\
\hline \multirow[t]{2}{*}{ Dependent variable } & $\mathrm{R} \& \mathrm{D}$ & $\mathrm{R} \& \mathrm{D}$ investment in corporate annual report \\
\hline & Patent & The number of patent applications in corporate annual report \\
\hline \multirow[t]{3}{*}{ Independent variables } & Rel & $\begin{array}{l}\text { The existence of government relationship, if has the political } \\
\text { relation Rel value is } 1 \text {, otherwise is } 0\end{array}$ \\
\hline & Relation & $\begin{array}{l}\text { Number of executives with government connections/total } \\
\text { number of executives }\end{array}$ \\
\hline & Relation $*$ Sub & Relation $*$ Subsidy/income \\
\hline \multirow{7}{*}{ Control variables } & Size & Ln(total assets) \\
\hline & Lev & Total liabilities/total assets \\
\hline & Grow & $\begin{array}{l}\text { (Final operating income-initial operating income)/initial } \\
\text { operating income }\end{array}$ \\
\hline & Roe & $\begin{array}{l}\text { Weighted return on net assets after deducting non-recurring } \\
\text { gains and losses at the end of the year }\end{array}$ \\
\hline & $\mathrm{CF}$ & Net cash flow from operating activities \\
\hline & Edu & $\begin{array}{l}\text { College degree or above, Number of employees/Total number } \\
\text { of employees }\end{array}$ \\
\hline & Liangzhi & $\begin{array}{l}\text { If the chairman and general manager are separated, Liangzhi } \\
\text { value is } 1 \text {,otherwise is } 0\end{array}$ \\
\hline
\end{tabular}

The explained variables include research and development input and patent applications. R\&D input is a manifestation of innovative potential of enterprises. The annual patent applications of enterprises provide a good proxy to indicate the actual quantity of technical innovation achievements acquired by enterprises. Therefore, we take patent applications as the measuring index of technical innovation achievements.

The explaining variable is political connection. As for the definition of political connections, we refer to the methods used in studies $[10,26]$, and define political connections by judging whether top executives of enterprises had previously assumed or presently assume such posts as government official, Deputy to the People's Congress representative and the Chinese People's Political Consultative Conference member. Top executives include directors, supervisors and senior management of companies.

With regard to the measurement of political connections, we select the dummy variable, the percentage of number of people and the scoring method, respectively. First, we set the dummy variables, and assign a value of 1 and 0 to existence and non-existence of political connections with enterprises respectively. Next, we take the percentage of the number of top executives with relationships to government to the total number of top executives of the enterprises as an index for measuring the political connections. The index obtained with this method, is not only more objective and capable of effectively eliminating the endogenous impact of subjective factors, but also makes the conclusions more accurate and reliable. Finally, we measure the strength of political connections with the scoring, for carrying out the robustness test. A score of 5, 4, 3, 2 and 1 is assigned to the institutions of officials, NPC representatives and CPPCC members according to central level, provincial level, municipal level, county / district level, township level and below respectively, and a score of 0 represents the absence of above experience. Finally, the scores are added together and the political connections of enterprises obtained.

In addition, considering the interaction between political connections and subsidies, we take the interaction between them as one of the explaining variables.

(3) Control variables. We control some factors that may impact technical innovation. The enterprise size is measured with the natural logarithm of total assets. Large-size enterprises are more capable of paying the research and development funds. The debt-to-assets ratio indicates the long-term debt-paying capacity of enterprises. The increase in rate of business revenue is an important index for evaluating the growth status and development capacity of enterprises. The strength of innovation investment of enterprises is subject to enterprise growth. The return on equity indicates 
the profitability of enterprises. The stronger the profitability of enterprises, the more the input of technical innovation may be. The size of enterprise cash flow impacts the size of enterprise annual input and investment in new technology. The level of employee education is measured by the percentage of the number of employees with junior college and above diplomas to the total number of employees in the companies. The level of human resources can help to promote the technical innovation capacity. A value of 0 is assigned to the duality and concurrency of the post of board chairman and general manager, and a value of 1 is assigned to the separation of the post of board chairman and general manager.

\subsection{Descriptive Statistics}

The statistical analysis is conducted, with the results shown in Table 2. As we can infer from Table 2, the standard deviation of the logarithm of enterprise $R \& D$ input is 1.842 , with the maximum value and the minimum value being 12.39 and 0.967 , respectively. Obviously, the mutual variance is not noticeable for all wind-energy companies, who will attach importance to the innovation. However, the standard deviation of annual patent applications among enterprises is as high as 65.75 , illustrating the gap of the innovative achievements among these firms.

Table 2. The descriptive statistics.

\begin{tabular}{cccccc}
\hline Variables & Sample Size & Mean & Std & Min & Max \\
\hline Ln(R\&D) & 202 & 8.203 & 1.842 & 0.967 & 12.39 \\
Patent & 238 & 44.34 & 65.75 & 0 & 422 \\
Rel & 238 & 0.727 & 0.446 & 0 & 1 \\
Relation & 238 & 14.87 & 13.00 & 0 & 52.63 \\
Relation $*$ Sub & 235 & 0.238 & 0.801 & 0 & 10.97 \\
Size & 235 & 13.56 & 1.425 & 9.100 & 17.04 \\
Lev & 237 & 339.8 & 4386 & 9.120 & 67572 \\
Grow & 233 & 16.79 & 28.20 & -34.79 & 225.6 \\
Roe & 235 & 0.397 & 3.111 & -1.740 & 42.53 \\
CF & 235 & 115,496 & 296,755 & $-538,287$ & $2.047 \times 10^{6}$ \\
Edu & 235 & 54.33 & 20.43 & 11.16 & 98.19 \\
Liangzhi & 235 & 0.553 & 0.498 & 0 & 1 \\
\hline
\end{tabular}

The mean value of the index of whether enterprises have political connections is 0.727 . This implies that about $70 \%$ of wind-energy companies actively set up relations with the government, hoping to better acquire corresponding preferential policies and government resources. Different enterprises have significant different connections with the government, with the maximum value being $52.63 \%$, although a small number of enterprises have not yet set up relationships with the government.

\subsection{Correlation Analysis}

Correlation analysis was conducted before regression. All the absolute values of correlation coefficients between variables are less than 0.6 , illustrating that serious multi-collinearity does not exist among variables. The mean value of Variance Inflation Factor was far less than 10 revealed no multi-collinearity.

\subsection{Empirical Results and Discussion}

4.5.1. The Impact of Existence/Non-Existence of Political Connections on the Innovative Capacity of Enterprises

To identify the impact of existence/non-existence of political connections on the innovative capacity of enterprises, we take the dummy variable of political connections as the explaining variable, and set up Model 1 and Model 2. The final regression result is shown in Table 3. 
Table 3. The regression results of political connections and enterprise innovation ability.

\begin{tabular}{ccc}
\hline Variables & Ln(R \& D) & Patent \\
\hline Rel & $-0.447^{*}$ & $-43.63^{* *}$ \\
Size & $(-2.000)$ & $(-2.077)$ \\
& 0.397 & 2.430 \\
Lev & $(0.935)$ & $(0.168)$ \\
& 0.00668 & 0.330 \\
Grow & $(1.007)$ & $(1.395)$ \\
Roe & 0.00103 & -0.179 \\
& $(0.426)$ & $(-1.585)$ \\
CF & $0.0125^{*}$ & 0.0686 \\
& $(1.774)$ & $(0.193)$ \\
Edu & $-3.47 \times 10^{-7}$ & $-3.11 \times 10^{-5}$ \\
& $(-0.646)$ & $(-0.859)$ \\
Liangzhi & $0.0314^{* *}$ & -0.391 \\
& $(2.151)$ & $(-0.628)$ \\
Constant & -0.205 & 42.37 \\
& $(-0.729)$ & $(1.434)$ \\
Observations & 1.264 & 29.73 \\
R-squared & $(0.246)$ & $(0.181)$ \\
Number of stkcd & 198 & 229 \\
& 0.185 & 0.123 \\
\end{tabular}

Note: In ( ) is the $t$ statistics after correction of heteroskedasticity. ${ }^{* * *},{ }^{* *}$ and ${ }^{*}$ represent the significance level of $1 \%$, $5 \%$ and $10 \%$ respectively.

As can be inferred from Table 3, when other conditions remain unchanged, the dummy variable of political connections of enterprises and the research and development input of enterprises are significantly negatively correlated at the $10 \%$ level, with the coefficient being -0.447 . This illustrates that, the existence of enterprises having political connections restrains R\&D funding in enterprises, which results in underinvestment in innovation, and impairs the innovative potential of enterprises. As indicated by the regression result of Model 2, when other conditions remain unchanged, the dummy variable of political connections and patent applications are significantly negatively correlated at the level of $5 \%$, with the coefficient being -43.63 . Thus, Hypothesis 1 is partly supported.

\subsubsection{The Impact of Political Connections and Subsidies on the Innovative Capacity of Enterprises}

By analyzing the above two models, we found that the political connections would have a significant negative impact on the technical innovation potential and the innovative performance. Then, does the strength of political connections between enterprises and the government have a remarkable impact on the technical innovation capacity of enterprises? Can a closer relationship between an enterprise and the government have a stronger negative impact on the innovative capacity of the enterprise? Model 3 and Model 4 were established for answering this question, with the regression result shown in Table 4.

Table 4 shows that, when other conditions remain unchanged, the political connections and R\&D input of enterprises are negatively correlated at the significant level of $10 \%$. This implies that, the higher the political connections of enterprises, the less R\&D input of enterprises. When other conditions remain unchanged, the political connections and patent applications of enterprises are significantly negatively correlated at the level of $5 \%$. Obviously, the closer the relationship between an enterprise and the government, the stronger the negative impact on the innovative achievements of the enterprise. This also partly fulfils Hypothesis 1. 
Table 4. The regression results of political connections, subsidies and enterprise innovation ability.

\begin{tabular}{|c|c|c|c|c|}
\hline \multirow{2}{*}{$\begin{array}{c}\text { Variables } \\
\text { Relation }\end{array}$} & \multicolumn{2}{|c|}{$\operatorname{Ln}(R \& D)$} & \multicolumn{2}{|c|}{ Patent } \\
\hline & $\begin{array}{l}-0.0141 * \\
(-1.919)\end{array}$ & $\begin{array}{l}-0.0143 * \\
(-1.966)\end{array}$ & $\begin{array}{l}-1.095^{* *} \\
(-2.580)\end{array}$ & $\begin{array}{l}-0.993^{* *} \\
(-2.314)\end{array}$ \\
\hline Relation $*$ Sub & $\begin{array}{l}-0.0205 \\
(-1.017)\end{array}$ & & $\begin{array}{c}10.59^{* * * *} \\
(9.790)\end{array}$ & \\
\hline Size & $\begin{array}{c}0.406 \\
(0.939)\end{array}$ & $\begin{array}{c}0.404 \\
(0.935)\end{array}$ & $\begin{array}{c}5.089 \\
(0.369)\end{array}$ & $\begin{array}{c}5.943 \\
(0.435)\end{array}$ \\
\hline Lev & $\begin{array}{c}0.00563 \\
(0.874)\end{array}$ & $\begin{array}{c}0.00563 \\
(0.875)\end{array}$ & $\begin{array}{c}0.267 \\
(1.124)\end{array}$ & $\begin{array}{c}0.264 \\
(1.113)\end{array}$ \\
\hline Grow & $\begin{array}{c}0.00117 \\
(0.488)\end{array}$ & $\begin{array}{c}0.00118 \\
(0.495)\end{array}$ & $\begin{array}{c}-0.131 \\
(-1.127)\end{array}$ & $\begin{array}{c}-0.137 \\
(-1.179)\end{array}$ \\
\hline Roe & $\begin{array}{c}0.000115 \\
(1.468)\end{array}$ & $\begin{array}{c}0.000116 \\
(1.498)\end{array}$ & $\begin{array}{c}0.000625 \\
(0.196)\end{array}$ & $\begin{array}{c}-0.000131 \\
(-0.035)\end{array}$ \\
\hline $\mathrm{CF}$ & $\begin{array}{c}-3.08 \times 10^{-7} \\
(-0.570)\end{array}$ & $\begin{array}{c}-3.05 \times 10^{-7} \\
(-0.567)\end{array}$ & $\begin{array}{c}-2.37 \times 10^{-5} \\
(-0.647)\end{array}$ & $\begin{array}{c}-2.53 \times 10^{-5} \\
(-0.682)\end{array}$ \\
\hline Edu & $\begin{array}{l}0.0311 * \\
(2.022)\end{array}$ & $\begin{array}{l}0.0311 * \\
(2.024)\end{array}$ & $\begin{array}{l}-0.486 \\
(-0.809)\end{array}$ & $\begin{array}{l}-0.453 \\
(-0.764)\end{array}$ \\
\hline Liangzhi & $\begin{array}{l}-0.242 \\
(-0.773)\end{array}$ & $\begin{array}{l}-0.246 \\
(-0.793)\end{array}$ & $\begin{array}{c}35.50 \\
(1.392)\end{array}$ & $\begin{array}{c}37.68 \\
(1.466)\end{array}$ \\
\hline Constant & $\begin{array}{c}1.110 \\
(0.213)\end{array}$ & $\begin{array}{c}1.137 \\
(0.218)\end{array}$ & $\begin{array}{l}-13.44 \\
(-0.085)\end{array}$ & $\begin{array}{l}-26.54 \\
(-0.169)\end{array}$ \\
\hline Observations & 198 & 198 & 229 & 229 \\
\hline R-squared & 0.185 & 0.185 & 0.110 & 0.086 \\
\hline Number of stkcd & 32 & 32 & 34 & 34 \\
\hline
\end{tabular}

Note: In ( ) is the $t$ statistics after correction of heteroskedasticity. ${ }^{* * *},{ }^{* *}$ and ${ }^{*}$ represent the significance level of $1 \%$, $5 \%$ and $10 \%$ respectively.

The results also revealed that, when other conditions remain unchanged, the interaction of political connections and subsidies had an insignificantly negative impact on research and development input. The interaction was significantly positively correlated with the patent applications of enterprises at the level of $1 \%$, with the coefficient being 10.59 . The subsidies would impair the negative effect of government relations on the innovative achievements of enterprises. The stronger the political connections are, the more easily the enterprises can acquire subsidies than those with a weaker political relevancy. Therefore, although the existence of political relations of enterprises would somewhat hinder the innovative capacity of enterprises, the regulatory function of subsidies can alleviate its negative effect. Hypothesis 2 is, therefore, untenable.

It should be noted that the amount of R\&D could be an independent variable to explain the performance of number of patents. For this reason, we retested models (2) and (4) by adding R\&D expenditure as one explanatory variable. Results showed that both $R \& D$ and its lagged term had no significant effect on the patents (see Tables 5 and 6).

Table 5. The regression results of political connections, subsidies and enterprise innovation ability (considering the research and development (R\&D) expenditure).

\begin{tabular}{ccc}
\hline Variables & Patent & Patent \\
\hline lnrd & -3.558 & -3.690 \\
& $(-0.970)$ & $(-1.022)$ \\
relation & $-1.148^{* *}$ & $-1.032^{*}$ \\
& $(-2.206)$ & $(-1.972)$ \\
Relation $*$ Sub & $10.72 * * *$ & \\
size & $(10.271)$ & \\
& -1.042 & -0.0293 \\
& $(-0.076)$ & $(-0.002)$ \\
\hline
\end{tabular}


Table 5. Cont

\begin{tabular}{ccc}
\hline Variables & Patent & Patent \\
\hline lev & 0.328 & 0.325 \\
& $(1.307)$ & $(1.283)$ \\
grow & $-0.181^{*}$ & $-0.187^{*}$ \\
roe & $(-1.747)$ & $(-1.788)$ \\
& 0.00190 & 0.00117 \\
cf & $(0.590)$ & $(0.303)$ \\
& $-5.71 \times 10^{-5}$ & $-5.89 \times 10^{-5}$ \\
edu & $(-1.251)$ & $(-1.276)$ \\
& -0.0869 & -0.0607 \\
liangzhi & $(-0.133)$ & $(-0.094)$ \\
& 35.56 & 37.68 \\
Constant & $(1.507)$ & $(1.579)$ \\
& 81.06 & 67.32 \\
Observations & $(0.457)$ & $(0.379)$ \\
R-squared & 198 & 198 \\
Number of stkcd & 0.144 & 0.117 \\
\end{tabular}

Note: In ( ) is the $t$ statistics after correction of heteroskedasticity. ${ }^{* * *}, * *$ and ${ }^{*}$ represent the significance level of $1 \%$, $5 \%$ and $10 \%$ respectively.

Table 6. The regression results of political connections, subsidies and enterprise innovation ability (considering the lagged effects of R\&D expenditure).

\begin{tabular}{|c|c|c|}
\hline Variables & Patent & Patent \\
\hline \multirow[t]{2}{*}{ L.lnrd } & -6.395 & -6.941 \\
\hline & $(-1.504)$ & $(-1.678)$ \\
\hline \multirow[t]{2}{*}{ relation } & $-1.192 *$ & $-1.091 *$ \\
\hline & $(-1.948)$ & $(-1.773)$ \\
\hline \multirow[t]{2}{*}{ Relation $*$ Sub } & $9.618^{* * *}$ & \\
\hline & $(7.772)$ & \\
\hline \multirow[t]{2}{*}{ size } & 1.672 & 2.584 \\
\hline & $(0.086)$ & $(0.135)$ \\
\hline \multirow[t]{2}{*}{ lev } & 0.331 & 0.306 \\
\hline & $(1.284)$ & $(1.227)$ \\
\hline \multirow[t]{2}{*}{ grow } & -0.189 & -0.192 \\
\hline & $(-1.465)$ & $(-1.502)$ \\
\hline \multirow[t]{2}{*}{ roe } & 0.00249 & 0.00272 \\
\hline & $(1.146)$ & $(1.271)$ \\
\hline \multirow[t]{2}{*}{$\mathrm{cf}$} & $-8.01 \times 10^{-5}$ & $-8.28 \times 10^{-5}$ \\
\hline & $(-1.430)$ & $(-1.469)$ \\
\hline \multirow[t]{2}{*}{ edu } & -0.284 & -0.226 \\
\hline & $(-0.435)$ & $(-0.356)$ \\
\hline \multirow[t]{2}{*}{ liangzhi } & 1.698 & 2.157 \\
\hline & $(0.330)$ & $(0.431)$ \\
\hline \multirow{2}{*}{ Constant } & 97.34 & 88.79 \\
\hline & $(0.378)$ & $(0.349)$ \\
\hline Observations & 168 & 168 \\
\hline R-squared & 0.148 & 0.124 \\
\hline Number of stkcd & 32 & 32 \\
\hline
\end{tabular}

Note: $\operatorname{In}()$ is the $t$ statistics after correction of heteroskedasticity. ${ }^{* * *}, * *$ and ${ }^{*}$ represent the significance level of $1 \%$, $5 \%$ and $10 \%$ respectively.

Additionally, we retested the relationship among the key variables by deleting the control variables and found the similar results. Compared with models with control variables, the R-squared value of the latter ones is lower and this illustrates the poor fit results. Therefore, we use the former models. 


\subsection{Robustness Test}

We conducted a robustness test on the models by employing the scoring method to re-measure the government relations.

No matter whether consideration is given to the interaction effect between political connections and subsidies, when other conditions remain unchanged, the strength of the political connections of enterprises was negatively related with both research and development input and patent applications. The interaction of strength of political connections and subsidies is insignificantly negatively correlated with the research and development input of enterprises. However, it has a positive impact on the patent applications at the level of $1 \%$, which coincides with the previous results. Therefore, our conclusion is robust.

\section{Conclusions and Policy Implications}

A total of 35 wind-energy companies were employed to examine the impact of political connections and subsidies on the technical innovation potential and innovative achievement of enterprises. The conclusions are as follows:

(1) The existence of government-enterprise connections had a significantly negative impact on innovative potential and innovative achievements. Therefore, as an important political resource, political connections impaired the innovative capacity of wind-energy companies. This is possibly because enterprises rely on the preferential policies of government excessively. Enterprises with political connections may lack the motivation to improve their own operation, resulting in the negative impact on the innovative capacity of enterprises.

(2) The strength of political connections is negatively related to the innovative potential and innovative achievement, in a remarkable manner. This indicates that enterprises with a higher strength of political connections lack research and development power and have insufficient innovative input, leading to a poorer innovative effect.

(3) Although political connections with enterprises will hinder the capacity of enterprises to innovate, the moderating function of subsidies can alleviate the negative effects. As a means to make up for market defects, the subsidies can produce a "stimulatory effect" on research and development, and enable enterprises to eventually achieve their innovative effect. The subsidies can effectively meet the demand of enterprises for capital, and remedy insufficient research and development, and financial shortages. The subsidies not only push enterprises to increase innovation, but also have a certain stimulatory effect on patent output.

To summarize, political connections impair the innovative capacity of enterprises but the modulation of subsidies can alleviate their negative effects. Accordingly, we put forward the following suggestions: (1) Wind-energy companies should gradually decouple the dependency on preferential policies, and achieve the upgrading and optimization of enterprises through technical innovation and business mode innovation, improving their scientific and technological competitiveness; (2) China should normalize the relevant laws and statutes relating to financial support and offer technical subsidies to wind energy enterprises based on the firms' characteristics, reducing the negative impact of political connections; (3) Wind-energy companies need to continuously reinforce their internal governance mechanisms for innovation, and perfect their supervisory systems with the purpose of promoting the efficient application of research and development funds.

Acknowledgments: This study is funded by the National Social Science Foundation of China (No. 13CGL094), Jiangsu Natural Science Foundation (No. BK20151527), the Priority Academic Program Development of Jiangsu Higher Education Institutions, Jiangsu Qinglan Project (2017[5]), Six Talents Peaks Project in Jiangsu Province (2015-XNY-008), The Special Project for the Jiangsu Philosophy Social Science (2017SJBFDY491), The Practice Innovation Training Program of College Students in Jiangsu Province (201610300073X).

Author Contributions: Jie Cao came up the original idea for the manuscript. Xinting Wang was responsible for data collection. Jiaan Qu and Jiexin Tang carried out the analysis. James O. Bukenya put forward the valuable suggestions and edited language for the policy implications. All authors read and approved the submission. 
Conflicts of Interest: The authors declare that they have no conflict of interest.

\section{References}

1. Luk, C.L.; Yau, O.H.M.; Sin, L.Y.M. The effects of social capital and organizational innovativeness in different institutional contexts. J. Int. Bus. Stud. 2008, 39, 589-612. [CrossRef]

2. Niu, X.Y. A Study on the Relationship between Political Relations and Government Subsidies in Senior Executives. Available online: http://xuewen.cnki.net/CJFD-BFJJ201320017.html (accessed on 22 September 2017).

3. Peng, M.W.; Luo, Y. Managerial ties and firm performance in a transition economy: The nature of a micro-Macro link. Acad. Manag. J. 2000, 43, 486-501. [CrossRef]

4. Song, M.L.; Ai, H.S.; Li, X. Political connections, financing constraints, and the optimization of innovation efficiency among China's private enterprises. Technol. Forecast. Soc. Chang. 2015, 92, 290-299. [CrossRef]

5. Zeng, P.; Lv, D.V.; Liu, Y. Technological innovation, political relevance and government innovation support: Mechanism and path. Sci. Res. Manag. 2016, 7, 17-26.

6. Zhang, Y.; Lu, H. A Study on the Influence of the Quality of Government Relationship on Enterprise's Innovation Performance. Available online: http://d.wanfangdata.com.cn/Periodical/kjhcy201610015 (accessed on 22 September 2017).

7. Shleifer, A.; Vishny, R.W. Politicians and firms. Q. J. Econ. 1994, 3, 599-617. [CrossRef]

8. Fisman, R. Estimating the value of political connections. Am. Econ. Rev. 2001, 91, 1095-1102. [CrossRef]

9. Bertrand, M.; Kramarz, F.; Schoar, A.; Thesma, D. Politicians, Firms and Political Business Cycle: Evidence from France. Available online: http://citeseerx.ist.psu.edu/viewdoc/summary?doi=10.1.1.592.1127 (accessed on 22 September 2017).

10. Fan, J.P.H.; Wong, T.J.; Zhang, T. Politically connected CEOs, corporate governance, and Post-IPO performance of China's newly partially privatized firms. J. Financ. Econ. 2007, 84, 330-357. [CrossRef]

11. Zhang, J.; Tan, J.; Wong, P.K. When does investment in political ties improve firm performance? The contingent effect of innovation activities. Asia Pac. J. Manag. 2015, 2, 363-387. [CrossRef]

12. Yuan, J.G.; Hou, Q.S.; Cheng, C. The Curse Effect of Corporate Political Resources: A Study Based on Political Relevance and Enterprise Technological Innovation. Available online: http:/ / www.cnki.com.cn/Article/ CJFDTotal-GLSJ201501015.htm (accessed on 22 September 2017).

13. Leyden, D.P.; Link, A.N. Why are governmental R \& D and private R \& D complements? Appl. Econ. 1991, 23, 1673-1681.

14. Mamunesa, S.J. The effects of government-industry R \& D programs on private R \& D: The case of the small business innovation research program. Rand J. Econ. 2000, 1, 82-100.

15. Holemans, C.T. Do subsidies have positive impacts on R \& D: Evidence from Congo. J. Struct. Chang. Econ. Dyn. 2009, 4, 209-223.

16. Matthias, A.; Czarnitzki, D. The effects of public R \& D subsidies on firms innovation activities: The Case of eastern Germany. J. Bus. Econ. Stat. 2003, 2, 226-236.

17. Clausen, T.H. Do subsidies have positive impacts on R \& D and innovation activities at the firm level? Struct. Chang. Econ. Dyn. 2009, 20, 239-253.

18. Montmartin, B. Centralized R \& D subsidy policy in an NEGG model: A welfare analysis. Rec. Écon. Louvain 2013, 1, 5-34.

19. Dumont, M.; Spithoven, A.; Teirlinck, P. Public support for R \& D and the educational mix of R \& D employees. Int. Conf. Integr. Technol. 2014, 347-360.

20. Louhivuori, V. Do public R \& D subsidies foster innovation? Evidence from finnish patent data. Renew. Energy 2015, 63, 330-336.

21. Zhu, P.F.; Xu, W.M. The impact of government's science and technology incentive policy on R \& D input and patent output of large and medium-sized industrial enterprises: An empirical study of Shanghai. Econ. Res. 2003, 6, 45-53.

22. Tong, G.R.; Gao, J. A Study on the Employment Multiplier Effect of Government R \& D Expenditure. Available online: http://cpfd.cnki.com.cn/Article/CPFDTOTAL-SLJJ200405001011.htm (accessed on 22 September 2017). 
23. Liu, S.D.; Zhang, Y.M. A Study on the Effect of Government R \& D Funding Driving SME Research and Development. Available online: http://www.cnki.com.cn/Article/CJFDTotal-XUXI201007009.htm (accessed on 22 September 2017).

24. Wang, Y.H. Government subsidy, R \& D investment and enterprise innovation performance: A study based on ownership, enterprise experience and regional difference. Inq. Econ. Issues 2013, 7, 138-143.

25. Gu, Q. The relationship between government subsidy and enterprise innovation investment and innovation mode: Evidence from small and medium-sized technological enterprises. Financ. Acc. 2015, 32, 74-76. (In Chinese)

26. Chen, M.M.; Zhang, G.S.; Sun, X. State-owned enterprises, government subsidies and innovative supply of enterprises: An empirical study based on listed industrial enterprises. Contemp. Financ. Econ. 2016, 10, 34-44.

27. Lichteber, F.R. The effect of government funding on private industrial and development: A reassessment. J. Am. Econ. Rev. 1988, 78, 550-559.

28. Busom, I. An empirical evaluation of the effects of R \& D subsidies. Econ. Innov. New Technol. 2000, 9, 111-148.

29. David, P.A.; Hall, B.H.; Toole, A. Is public R \& D a complement or substitute for private R\&D? A review of the econometric evidence. Res. Policy 2000, 4-5, 497-529.

30. Impullitti, G. International competition and U.S. R\&D subsidies: A quantitative welfare analysis. Int. Econ. Rev. 2010, 4, 1127-1158.

(C) 2017 by the authors. Licensee MDPI, Basel, Switzerland. This article is an open access article distributed under the terms and conditions of the Creative Commons Attribution (CC BY) license (http://creativecommons.org/licenses/by/4.0/). 